\title{
COVID-19 Pandemic and Its Implications on Small and Medium Enterprises (SMEs) Operations in Zambia
}

\author{
Clement Mwaanga ${ }^{1}$, James Mulenga ${ }^{2}$, Mary Lubinda ${ }^{1}$, Moulen Siame ${ }^{1}$, Kunda Kaliba-Chishimba ${ }^{2}$, \\ Mulenga Chonzi Mulenga ${ }^{2} \&$ Chilala Sheila Kafula ${ }^{2}$ \\ ${ }^{1}$ School of Business Studies, Mulungushi University, Zambia \\ ${ }^{2}$ School of Social Science, Mulungushi University, Zambia \\ Correspondence: Clement Mwaanga, School of Business Studies, Zambia.
}

Received: January 25, 2021

Accepted: March 18, 2021

Online Published: May 8, 2021

doi:10.5430/jbar.v10n1p32

URL: https://doi.org/10.5430/jbar.v10n1p32

\begin{abstract}
The COVID-19 pandemic has slowed down the operations of enterprises of different sizes and types in different ways. The most affected are the SMEs operating in various sectors of the economy. This study sort to investigate the influence of the COVID-19 pandemic on the operations of SMEs in the food and accommodation industry and provide policy recommendations to the government on supportive measures for SMEs. We employed an exploratory methodology with a critical review of available literature, including policy documents, research papers, and relevant literature to the sector Data was collected from four provinces using a survey method, and analysis was conducted through descriptive statistics. The findings indicate that most of the SME's monthly revenues have gone down by more than 50 percent and they are facing challenges such as failing to pay workers, restricted number of customers, and high cost of inputs. Besides, 21 percent of the SMEs reported improved adherence to health guidelines as one of the mitigating factors to minimise the spread of the COVID-19 pandemic. Furthermore, only 4 percent of the SMEs have accessed financial support from Government but their businesses have remained the same. Based on these findings, policy recommendations have been made to help SMEs survive during the crisis.
\end{abstract}

Keywords: COVID-19, lockdown, food and accommodation, operations, sector

\section{Introduction}

From the time China reported the first case of the COVID-19 at the end of 2019, the virus has been spreading to other parts of the world affecting human life and the operations of businesses. Nearly all the parts of the world have been affected and have been recording an average mortality rate of between 8.3 to 12 percent (WHO, 2020). It is estimated that most enterprises will experience a reduction in operating revenues due to the disruption of supply chains, changes in market confidence, reduced numbers of consumers, and reduction in investment which has weakened the global economic activity (UNDP, 2020). All these pose even greater challenges for the resilience and governance of impacted economies.

In response to the World Health Organisation (WHO) pronouncement, the Government of the Republic of Zambia through the Ministry of Health established preventative and control measures to upscale national preparedness, surveillance, and response to the threat of the outbreak (ZNPHI, 2020). Some of the measures implemented include the following; review of the issuance of Visas for travellers to Zambia from countries affected by the Covid-19; mass testing, restriction of public gathering to at least 50 people; Adjustment of normal operations of restaurants to only operate on takeaway, closure of drinking and entertainment places and closure of all international airports except for Kenneth Kaunda International Airport to minimise the spread of the virus among others (ZNPHI, 2020).

To reduce the impact of the Covid-19 on the operations of Small and Medium Enterprises (SMEs), the Zambian government provides a stimulus package for medium-term liquidity (Business Survey, 2020). Therefore, the partial lockdown for Zambia was both a historic and necessary step for countering the spread of the virus and some of these measures have been eased and the economy is opening up slowly.

\subsection{Importance of SMEs to an Economy}

SMEs dominates the businesses in Zambia and play a significant role in providing employment to the citizens and influences economic growth (MCTI, 2020). This sector constitutes 97 percent of businesses in Zambia, accounting for 
70 percent of the country's GDP and contributes 88 percent of employment (UNDP, 2020). In society, the sector is playing a significant role in employing the most vulnerable segments of the workforce especially the youths. Although the sector has made positive contributions to the economy and society at large, its growth has been hindered by their inability to access capital (GEM, 2014). To eliminate this barrier, the government in conjunction with the United Nations Development Programme (UNDP) have proposed the introduction of a credit guarantee scheme amid at providing low interest, long-term loans to Zambian SMEs, to enhance formalisation of businesses, skills development, develop industry clusters, improve the value-chain linkages and offer business development services to SMEs (MCT1, 2020). During the period of the Covid-19, the raid assessment report on mitigating the social and economic impact of Covid-19 in Zambia indicated that the pandemic would harm their businesses most of the SME owner-managers are worried about the how the COVID-19 pandemic has continued to affect their income and their ability to meet expenditures like salaries, and wages, and rentals (UNDP, 2020).

\subsection{Food and Accommodation Industry}

In the recent past, the food and accommodation industry in Zambia has shown some significant signs of growth. The sector has been identified by the Government as a priority area for future investment because of its knock-on effects on other sectors (ZDA, 2013). Worldwide, the sector accounts for 10 percent of the global GDP (Tabetando, 2020). However, it is projected that the global sector's contribution will decline by 1.5 percent and global trade volume by 3.7 percent (Mckibbin \& Fernando, 2020). In Zambia, the sector contributed about 7 percent of the GDP (USD 1,701) and provide for 7.2 percent employment ( 469,000 jobs) with revenues from international visitors of about USD 849 million representing an average of 10 percent of the country's export (Tabetando, 2020). Although Zambia has witnessed a significant increase in the number of international visitors, the country still lags behind South Africa and Zimbabwe. Figure 1 shows the number of tourist to Zambia and its other African countries.

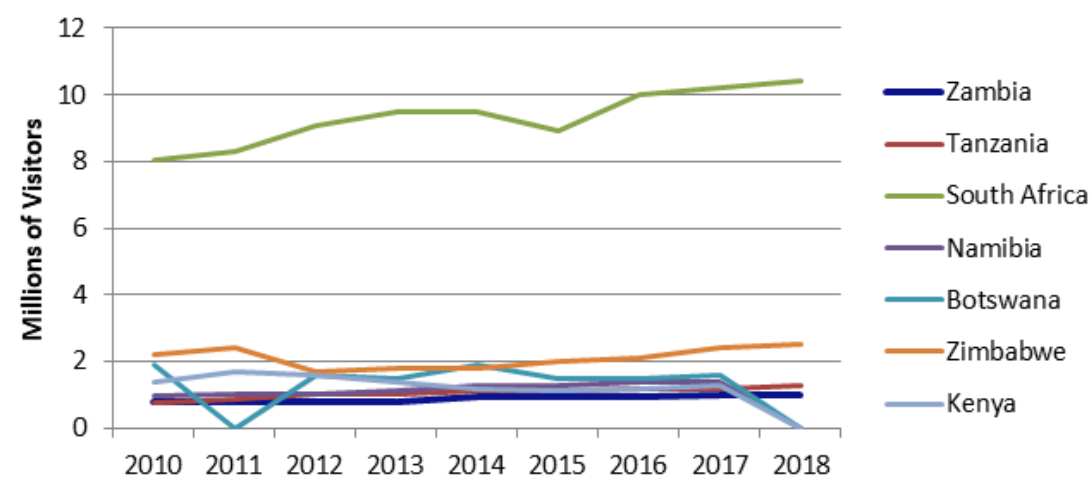

Figure 1. Number of tourist to Zambia and other African countries

Source: Tabetando (2020)

The food and accommodation industry has not been spared by the COVID-19 pandemic in almost all economies. In Zambia, the new COVID-19 health guidelines and the closure of eating and drinking laces coupled with the limiting of public gathering, have reduced the economic activities of the SMEs especially in catering and accommodation subsector and they are expected to experience activities between 70 percent and 80 percent (UNDP, 2020).

\section{Literature Review}

A body of literature has indicated that the sector has become vulnerable to the pandemic because it relied on human mobility and very close interactions (Gallen, 2020; Huang, 2020; Hao, Xiao, \& Chao, 2020). The sector is also vulnerable to natural calamities such as earth quicks, world fires, floods, volcano explosions, and other diseases (Rogerson \& Rogerson, 2020). In such situations, concerns are raised about the health and personal safety of citizens in a country resulting in the implementations of the same measures to mitigate the effects. With the COVID-19 pandemic, the result of lockdown measures such as restrictions in the movements and social distancing implemented in many countries, subjected the food and accommodation sector to several challenges including the following, reduced numbers of customers, a reduction in operating hours, loss of revenues and loss of jobs by employees (UNDP, 2020; Sun et al., 2020; Zhang et al., 2020). According to Elena (2020), the reduction in sales revenues and working hours has compiled most of the players in the industry to reduce their investment which has affected the performance of the 
sector. A study conducted in China on 498 hotels indicated a decline in revenues of 10 percent in the first quarter of 2020 and more than 85 percent revenues in the second quarter (Zhang et al., 2020). Other studies have also looked at the impact of COVID-19 on other aspects of the food and accommodation sector.

From the time the first infection was reported in Zambia, studies have been conducted to determine the impact of COVID-19. Most of the studies conducted on the impact of the COVID-19 pandemic in Zambia have focused on the social-economic impact of SMEs operating in various sectors of the economy (Mukosa et al., 2020; Mwiinga et al., 2020; Business Survey, 2020; UNDP, 2020).

To the best of our knowledge, this is the first study in Zambia to investigate the COVID-19 pandemic impact of food and accommodation. Therefore, catering and accommodation sector being a vital sector of an economy, this call for an understanding of the impact of the Covid-19 pandemic on SME operations in the new normal, challenges being faced, measures put in place to mitigate the impact, and the support needed by SMEs to survive during the pandemic.

\section{Methodology}

To meet the objective of this study, we employed an exploratory methodology by conducting an extensive review of the existing literature on the impact of COVID-19 on the food and accommodation industry, government policy documents, and COVID-19 publications by cooperating partners. Additionally, empirical evidence was sought by conducting personal interviews and administering a questionnaire physically to the owner/managers in the sector to ensure a high response rate since the country is not under lockdown. The sampling frame for this study consisted of a list of registered SMEs in four provinces, Lusaka, Central, Southern, and Copperbelt with provincial chambers of commerce from which a random sample of 450 SMEs was drawn purposively according to the size and sub-sectors.

During the data collection period, COVID-19 health guidelines were adhered to by the researchers. The survey contained basic questions such as the demographic profile of respondents, business characteristics, and the impact of COVID-19 on monthly revenues, challenges faced, measures put in place, financial support received from the government, and the support needed by SMEs. To ensure clarity and relevance of the questionnaire items, the instrument was pre-test on SMEs based in Central province and potential issues were discarded.

\section{Findings}

In this study, 450 questionnaires were distributed to SMEs in the food and accommodation industry, only 437 were completed and returned, representing a $97.1 \%$ response rate. The majority of the SMEs who participated in this study (Figure 2) are based in the central province (33\%), followed by Southern province (23\%) and Copperbelt and Lusaka provinces $(23 \%)$ each.

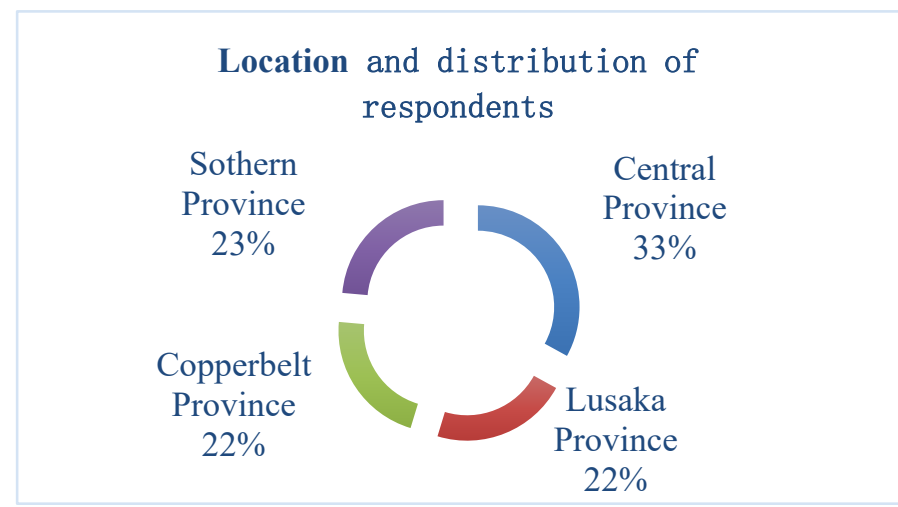

Figure 2. Location and distribution of respondents

\subsection{Demographic Characteristics of the Sample}

In terms of gender, the food and accommodation industry is female-dominated with $61 \%$ and male $38.7 \%$ (Table 1 ). The findings are in contrast to the assertion that men are more likely to take entrepreneurship as a career option than women (Brush, 1992). Furthermore, women face challenges in organizing start-up capital and managing the business (Becker-Blease \& Sohl, 2007) and that an entrepreneur should possess society's masculine characteristics (Ahl, 2006). 
Table 1. Demographic Characteristics of the Sample

\begin{tabular}{llcc}
\hline Demographic Characteristics & Variables & Frequency & $\mathbf{\%}$ \\
\hline \multirow{2}{*}{ Gender } & Male & 169 & 38.7 \\
& Female & 268 & 61.3 \\
\hline \multirow{3}{*}{ Age } & Below 25 years & 67 & 15.3 \\
& Between 26-35 years & 197 & 45.1 \\
& Between 36-45 years & 101 & 23.1 \\
& Above 46 years & 72 & 16.5 \\
\hline \multirow{3}{*}{ Level of Education } & Certificate & 225 & 51.5 \\
& First Degree & 139 & 31.8 \\
& Diploma & 49 & 11.2 \\
& Master's Degree & 4 & 0.9 \\
Position & PhD & 2 & 0.5 \\
\hline \multirow{3}{*}{ Experience } & Owner & 153 & 35 \\
& Manager & 133 & 30.4 \\
& Employees & 151 & 34.6 \\
\hline
\end{tabular}

On the age distribution of respondents, $45.1 \%$ were aged between 26 and 35 years, $23.1 \%$ between 36 and 45 years, $16.5 \%$ above 46 years while the least $15.3 \%$ were below 25 years. The majority of the respondents are youths indicating the industry employs more youths and at the same time, they are the majority owner managers. The findings have also revealed that most of the employees and owner-managers (51.5\%) are certificate holders, followed by first-degree holders (31.8\%), diploma holders (11.2\%), and Master's degree and $\mathrm{PhD}$ holders $(0.9$ and $0.5 \%$ respectively). Being a low skilled industry, the majority of respondents have certificates (mostly workers) followed by first degree holders who maybe owner-managers. Positions of respondents on the other hand suggest that $35 \%$ were owners, $34.6 \%$ employees, and 30.4\% managers. Since the majority of the respondents are certificate holders, it can be concluded that entrepreneurship education introduced in higher and tertiary institutions of learning is not effective to influence graduates to take entrepreneurship as a career option. Seun (2016) suggested that entrepreneurship education is meant to influence an individual's intentions to engage in entrepreneurial activities.

\subsection{Business Characteristics}

The food and accommodation industry has different types of subsectors. In this study, only two subsectors were considered. The findings (Table 2) indicated that $50.1 \%$ of the businesses considered in this study were restaurants and $49.9 \%$ lodges. 
Table 2. Business Characteristics

\begin{tabular}{llcc}
\hline Business Characteristics & Variable & Frequency & \% \\
\hline \multirow{2}{*}{ Business type } & Restaurant & 219 & 50.1 \\
& Lodge & 218 & 49.9 \\
\hline \multirow{3}{*}{ No. of employees } & 1 to 4 workers & 140 & 32 \\
& 5 to 9 workers & 148 & 33.9 \\
& 10 to 14 workers & 81 & 18.5 \\
& 15 to 19 workers & 39 & 8.9 \\
& 20 or more workers & 29 & 6.6 \\
\hline
\end{tabular}

Some $33.9 \%$ of the businesses employed between 5 to 9 workers, $32 \% 1$ to 4 workers, $18.5 \% 10$ to 14 workers, $8.9 \%$ 15 to 19 workers, and $6.6 \% 20$ or more workers. Most of the businesses considered in this study are micro-enterprises according to the Ministry of Commerce and Industry classification (MCTI, 2004).

\subsection{Impact of COVID-19 on Business revenue}

On the impact of COVID-19 on monthly revenues of the businesses in the industry, the study revealed that $42.4 \%$ have experienced above $50 \%$ reduction in monthly revenue, $39.6 \%$ indicated less than $50 \%$ reduction. These results are consistent with previous studies (Sun et al., 2020; Zhang et al., 2020; Elena, 2020) who reported the loss of revues experienced by businesses in the food and accommodation industry due to the COVID-19 pandemic.

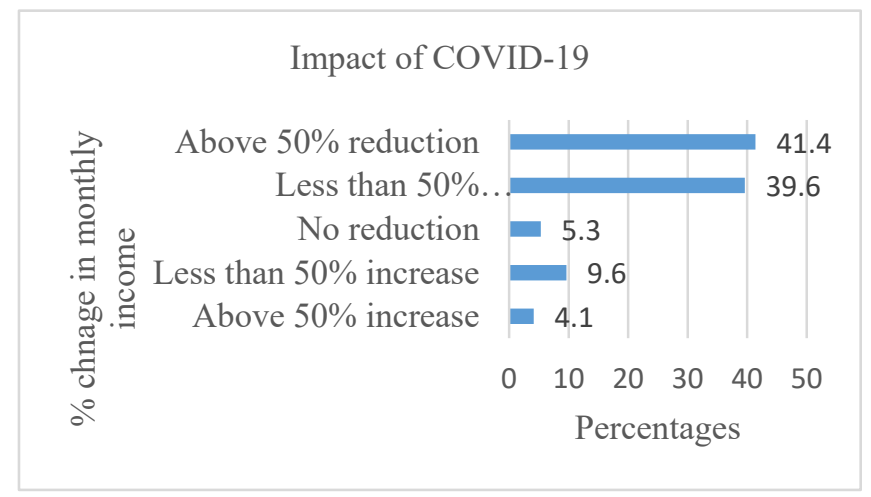

Figure 2. Impact of COVID-19 on monthly revenue

On the other hand, $9.6 \%$ of the businesses reported a less than $50 \%$ increase in revenue and $4.1 \%$ above $50 \%$ increase in revenue. Only $5.3 \%$ of the businesses reported a non-reduction in business revenue.

\subsection{Challenges and Measures}

Of the 437 respondents, $21 \%$ reported a restricted number of customers as a challenge, $19 \%$ indicated a high cost of inputs while $17 \%$ failing to pay workers (Figure 3). Furthermore, $11 \%$ indicated nature of the product, $10 \%$ lack of infrastructure, $9 \%$ failure by customers to adhere to health guidelines, $8 \%$ liquidity problems, $4 \%$ cited other challenges like failing to pay rent and customers negotiating for lower prices and $3 \%$ employees working from home. 


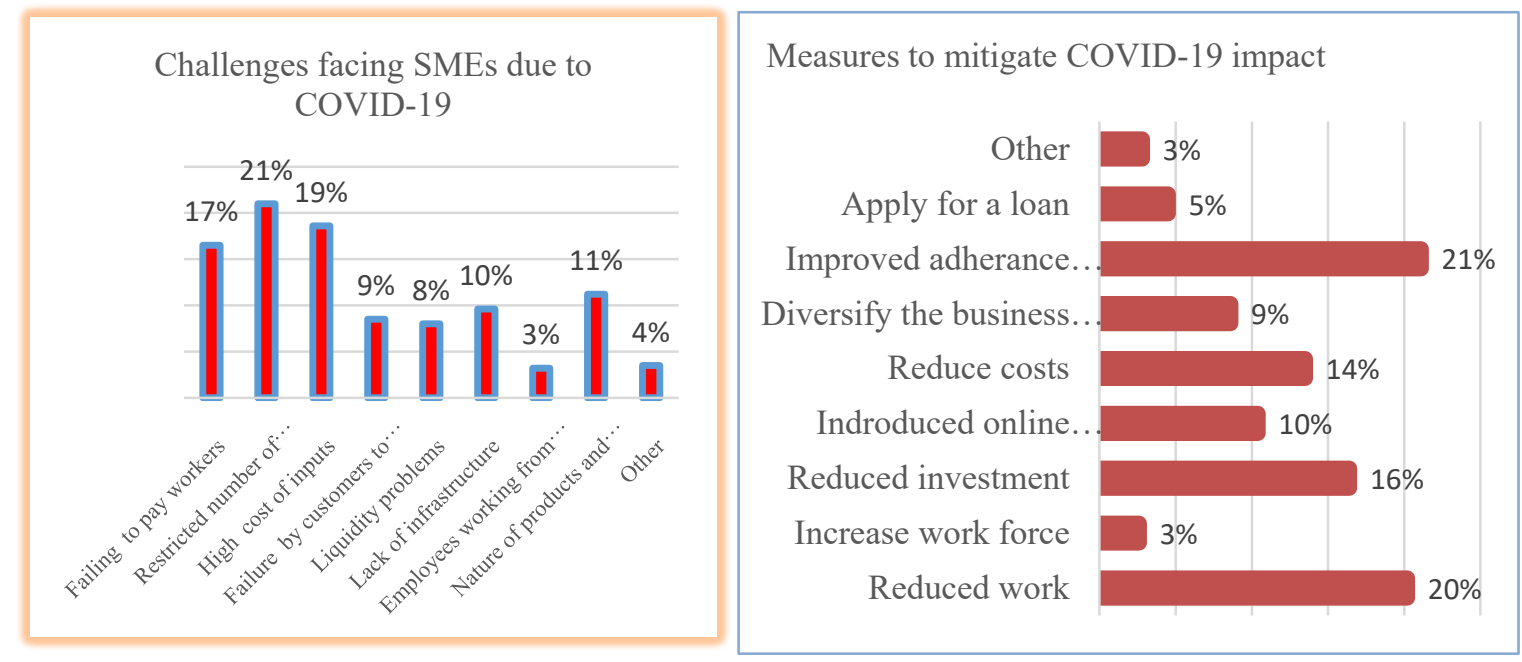

Figure 3. Challenges SMEs are facing and Measures to mitigate COVID-19 impact

With regards to measure put in place to mitigate the impact of COVID-19, the majority of the businesses (21\%) reported improved adherence to health guideline, followed by reduced work $(20 \%)$, reduced investment (16\%), cost reduction $(14 \%)$, introduced online services $(9 \%)$, applied for a loan $(5 \%)$ while increased workforce and other represented by $3 \%$ each.

\subsection{Government Stimulus Package}

On whether SMEs have received financial support (Figure 4), the results revealed that only $4 \%$ have accessed it, the majority of them (85\%) have not, and $11 \%$ are not aware of its existence. Those who have received financial support, most of them (52\%) indicated that business is the same while $24 \%$ reported improved business and that business has gone down (24\%),

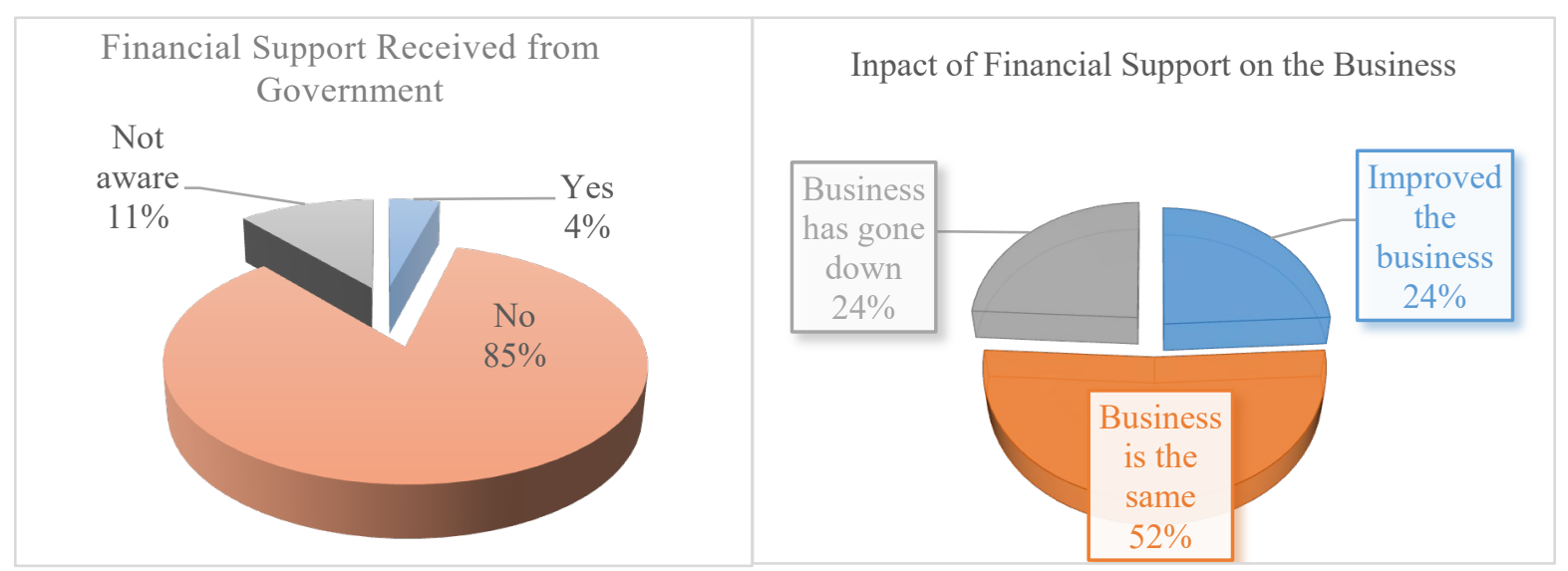

Figure 4. Financial Support received from government and its impact

\subsection{Reasons for not Accessing Financial Support}

Those who have not accessed financial support from the government reported the following reasons; not aware of the package (53.1\%), aware but do not know where to get it (21.7\%), aware but don't know the application guideline (9.6\%) aware but do not know the requirements $(8 \%)$ and aware but not interested (1.1\%). 


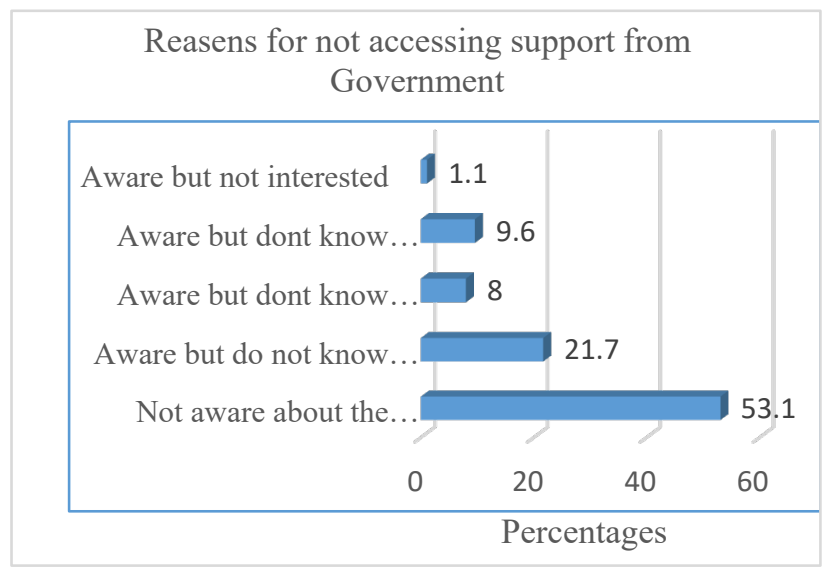

Figure 5. Reasons for not accessing financial support

\subsection{Assistance needed from Government}

When owner-managers were asked about the assistance needed from the government (figure 6), the findings indicated that $29 \%$ need cash grant, $22 \%$ subsidies in utilities, $20 \%$ low-interest loans, $19 \%$ subsidies in tax, $9 \%$ technical support, and others like reducing load shedding hours and Reduced trading licenses (Trade permits, health certificates, tourism levies) $2 \%$.

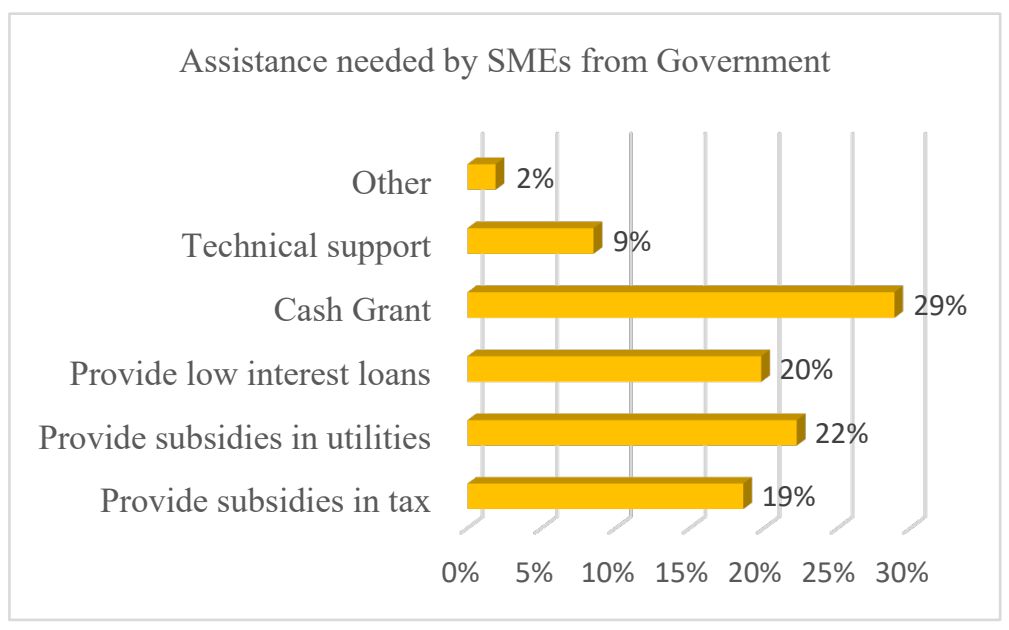

Figure 6: Assistance needed from the government

\section{Conclusion}

While COVID-19 has been reported to have a severe impact on the health sector worldwide, the food and accommodation sector in Zambia is not exceptional. The study has reported how the sector has been affected by the COVID-19 and the partial lockdown imposed by the government early last year which resulted in the closure of most businesses in the country especially those in the food and accommodation sector. As a result of this action, most of the SMEs in this sector reported a reduction in monthly revenue which has affected their day to day running of their businesses and the livelihood of the people in society as a whole. This was also attributed to the restricted number of customers accessing the business areas and the high cost of inputs which limited also their ability to pay workers.

To mitigate the effects of COVID-19, SMEs improved adherence to health guidelines, reduced working hours, and reduced investment while others opted to apply for a loan and offer online services. Some SMEs accessed the Government Stimulus Package, and the majority of them had not and were not even aware of its existence. Despite having benefited from the government package, some SMEs still experienced challenges due to partial lockdown, and only a few SMEs recorded an increase in their businesses. However, the majority of SMEs could not access financial 
support from the government because they were not aware of its availability and those who were aware did not know where to get it from and the application guidelines and requirements. Considering these findings, it may be concluded that, the information surrounding the government stimulus package was not available. This might have contributed to the low number of applicants and low numbers of beneficiaries

\section{Policy Recommendations}

Indeed, the sector understudy has been adversely affected by COVID-19 and requires a rifle approach policy to revitalize the sector. Arising from the findings in figure 6 , the following policy recommendations are recommended for policymakers to consider the following:

- The Zambian government through quartzite government financial institutions such as Citizens Economic Empowerment Commission (CEEC), National Technological Business Centre (NTBC), Zambia Development Agency (ZDA), National Savings and Credit Bank (NATSAVE), and Micro Bankers Trust (MBT) should allocate a certain amount of affordable loan fund to this sector and conduct awareness campaigns by advertising on print and electronic media and other platforms so that the information can rich these entrepreneurs.

- Through ZRA, the government should provide a tax break to these SMEs whose revenues have been affected by the COVID-19 pandemic.

\section{References}

Ahl, H. (2006). Why research on women entrepreneurs needs new dimensions. Entrepreneurship theory and practice, 30, 595-621. https://doi.org/10.1111/j.1540-6520.2006.00138.x

Becker-Blease, J. R., \& Sohl, J. E. (2007). Do women-owned businesses have equal access to angel capital? Journal of business venturing, 23, 503-521. https://doi.org/10.1016/j.jbusvent.2006.06.003

Brush, C. G. (1992). Research on women business owners: Past trends, a new perspective, and future direction. Entrepreneurship theory and practice, 16(4). 5-30. https://doi.org/10.1177/104225879201600401

Elena, (2020). The Q1 RevPAR of Huazhu hotel dropped by more than half, and the RevPAR of Deutsche Hotel dropped by $21 \%$. Retrieved from http://traveldaily.net/article/137334

Fei, H., Qu, X., \& Kaye, C. (2020). COVID-19 and Chines hotel industry: Impact on disaster management framework and post-pandemic agenda. International Journal of hospitality and management, (9), 102636. https://doi.org/10.1016/j.ijhm.2020.102636

Gallen, S. (2020). The response of tourism businesses vis-à-vis the economic ramifications of SARS-CoV-2. Retrieved from AIEST. https://www.aiest.org/news/

Global Entrepreneurship Monitor report. (2014). Zambia: Corporate Face. February 2014.

Huang, C. (2020). Coronavirus: For China, economic pain has only just begun. Retrieved from https://www.scmp.com/week-asia/opinion/article/3076175/Coronavirus-china-economic-pain-has-only-just-beg un

McKibbin, W. J., \& Fernando, R. (2020). The global macroeconomic impacts of COVID-19: Seven scenarios. https://doi.org/10.2139/ssrn.3547729

Ministry of Commerce Trade and Industry. (2004). The Micro, Small and Medium Enterprise Development Policy, Lusaka, Zambia.

Ministry of Commerce Trade and Industry. (2020). The impact of COVID-19 on SMEs in Zambia. The business Survey report, August 2020.

Mukosa, F., Mweemba, B., Mwitumwa, L., Mbewe, S. B., Sikazwe, W., \& Sinkala, N. K. (2020). The impact of COVID-19 on small-medium enterprises in Zambia. Banking and Insurance academic journal, 2, 6. http://41.63.8.17:80/jspui/handle/123456789/92

Mwiinga, B., Sikazwe, W., Kangwa, V.Z., Katebe, M., \& Matafwali, M. (2020). Operational strategies of small and medium enterprises in Lusaka-post COVID-19. American research journal of human and social sciences, 3, 7. http://41.63.8.17:80/jspui/handle/123456789/85

Rayner Tabetendo. (2020). Tourism and COVID-19 in Zambia. Retrieved from https://www.theigc.org/blog/tourism-and-covid-19-in-Zambia/\#: :text=COVID\%2D19\%20is\%20a\%20real,reco very $\% 20$ when $\% 20$ international $\% 20$ travel $\% 20$ resumes.\&text=International $\% 20$ visitors $\% 20$ spent $\% 20$ USD $\% 208$ $49,10 \% 25 \% 20$ of $\% 20$ Zambia's $\% 20$ total $\% 20$ exports 
Rogerson, C. M., \& Rogerson J. M. (2020). COVID-19 and Tourism Spaces of Vulnerability in South Africa. African Journal of Hospitality, Tourism, and Leisure, 9(4), 382-401. https://doi.org/10.46222/ajhtl.19770720-26

Seun, A. O. (2016). Exploring entrepreneurial readiness of youths and start-up success components: Entrepreneurship training as a moderator. Journal of Innovation and Knowledge, 2, 155-175. https://doi.org/10.1016/j.jik.2016.12.004

Sun, Z., Li, R., He, P., Shi, Y., et al. (2020). Perspective crisis: The Impact of COVID-19 on Hotel Industry and Its Response. Retrieved from Huamei Consulting https://wwwmeadin.com/yj/212678.html

United Development Nations Programme. (2020). Business Survey Report on the Impact of COVID 19 on Zambian Enterprises. June 2020.

United Development Nations Programme. (2020). Assessment Report on Impact of COVID-19 Pandemic on Chinese Enterprises. March 2020.

United Development Nations Programme. (2020). Mitigating the Socio-economic impact of COVID-19 in Zambia. A rapid assessment. April 2020.

World Health Organisation. (2020). Covid-19 Situational Analysis. February 2020.

Zambia Development Agency. (2020). Tourism sector profile. June 2013.

Zambia National Public Health Institute. (2020). COVID-19 situational report, October 2020. Retrieved from https://znphi.co.zm/news/

Zhang, C., Cui, R., Xu, C., \& Wang, J. (2020). COVID-19 and the Chinese Hotel Sector. Retrieved from HVS https://www.hvs.com/article/8723-COVID-19-and-the- Chinese-Hotel-Sector

\section{Copyrights}

Copyright for this article is retained by the author(s), with first publication rights granted to the journal.

This is an open-access article distributed under the terms and conditions of the Creative Commons Attribution license (http://creativecommons.org/licenses/by/4.0/). 